\title{
PENGGUNAAN PREDATOR UNTUK MENGENDALIKAN KUTU KEBUL (BEMISIA TABACI), VEKTOR PENYAKIT KUNING PADA CABAI DI KABUPATEN TANGGAMUS
}

\author{
Sudiono $^{1}$ \& Purnomo $^{1}$
}

\begin{abstract}
Application of predators to control whitefly (Bemisia tabaci), an insect vector of yellow diseases of chili in Tanggamus district on dry and rainy season. The yellow disease is one of the important diseases in chili which is transmitted by whitefly. Utilization of natural enemy such as predators is one of some methods in controlling whitefly. This study was conducted in Gisting, Tanggamus District, Lampung province from June 2009 to January 2010. The objective of this research was to determine effectiveness of controlling whitefly by its predators: Menochilus sp., Micraspis sp., and Paederus sp. The results showed that Menochilus, Micraspis, and Paederus could effectively decrease the population of whitefly. The three predators were more effective in rainy than in dry season.
\end{abstract}

Key words: Bemisia tabaci, yellow disease, chili, predator

\section{PENDAHULUAN}

Penyakit kuning pada tanaman cabai merupakan salah satu penyakit penting yang saat ini memberikan andil permasalahan baru pada tanaman cabai selain penyakit dan hama yang lain. Penyakit kuning pada cabai disebabkan oleh virus, sampai saat ini telah dilaporkan lebih dari 30 virus yang secara alami dapat menyerang tanaman cabai (Green \& Kim, 1991). Di antara virus-virus yang dapat menyerang tanaman cabai adalah virus gemini yang saat ini paling merugikan. Di Indonesia virus gemini pertama kali diketahui menyerang tanaman tembakau di Bojonegoro, Jawa Timur dan mengakibatkan kerusakan sebesar $30 \%$ (Poerbokoesoemo, 1984 dalam Trisusilowati et al., 1990). Infeksi virus gemini juga telah terdeteksi pada tanaman cabai di daerah Jawa Barat, DI Yogyakarta dan Kalimantan Selatan (Rusli et al., 1999; Sulandari et al., 2001; Aidawati et al., 2001), dan pada tanaman tomat di Jawa Barat (Sudiono et al., 2001). Serangan virus gemini pada pertanaman cabai di daerah Segunung, Bogor mencapai $100 \%$ dan dapat mengakibatkan kerugian yang sangat besar bagi petani cabai. Tingginya serangan ini diduga berkaitan dengan populasi kutu kebul (Rusli et al., 1999). Di Sumatera, hampir semua daerah telah terinfeksi virus gemini dengan kejadian penyakit berkisar 30-100\% (Sudiono et al., 2005).
Virus gemini ditularkan hanya oleh vektor, yaitu vektor kutu kebul Bemisia tabaci. Kutu kebul pertama kali diidentifikasi pada tahun 1897 di Amerika Serikat pada tanaman kentang dengan nama asli Aleyrodes inconspicua yang merupakan hama utama pada tanaman di rumah kaca pada tanaman tomat, cabai, kedelai, dan beberapa tanaman lainnya (Oliveira et al., 2001). Menurut Kalshoven (1981), tumbuhan dalam famili Compositae, Cucurbitaceae, Cruciferae, dan Solanaceae merupakan inang bagi kutu kebul. Selanjutnya dinyatakan bahwa kutu kebul merupakan serangga vektor bagi penularan beberapa penyakit tumbuhan.

Pengendalian kutu kebul di beberapa negara dilakukan dengan insektisida (Palumbo et al., 2001), predator dan parasitoid (Gerling et al., 2001), praktek budidaya (Hilje et al., 2001), dan tanaman tahan (Bellotti et al., 2001). Seperti halnya serangga hama yang lain, kutu kebul juga mempunyai musuh alami. Beberapa predator seperti Chrysoperla sp., Orius sp., Delphastus catalinae, dan Nephapsis oculatus efektif menekan populasi kutu kebul di Florida Amerika Serikat (McAuslanes, 2001). Gerling et al., (2001) menyatakan bahwa kutu kebul dapat dikendalikan secara hayati dengan memanfaatkan predator dan parasitoid. Hasil penelitian Purnomo et al. (2009) menunjukkan adanya musuh alami yang berasosiasi dengan kutu kebul, yakni

\footnotetext{
${ }^{1}$ Jurusan Proteksi Tanaman, Fakultas Pertanian, Universitas Lampung,

Jl. Sumantri Brojonegoro No. 1 Bandar Lampng 35145. E-mail: sudiono@unila.ac.id
} 
berupa 5 jenis predator dan 1 jenis parasitoid: Paederus sp., Menochilus sp., Micraspis sp., Delphastus sp, Oxyopes sp., dan Encarsia sp. Penelitian ini bertujuan untuk mengetahui efektivitas tiga jenis predator dalam menekan populasi kutu kebul pada pertanaman cabai.

\section{METODE PENELITIAN}

Penelitian ini dilaksanakan di lahan petani di daerah sentra pertanaman cabai Kecamatan Gisting, Kabupaten Tanggamus. Penelitian dilakukan pada musim kemarau dan musim hujan, mulai bulan Juni 2009 sampai Januari 2010.

Percobaan disusun dalam Rancangan Acak Kelompok, terdiri atas 4 perlakuan ( 1 kontrol dan 3 jenis predator) dengan 3 ulangan. Perlakuan ditentukan berupa: (1) kontrol (tanaman cabai +100 ekor kutu kebul, tanpa predator), (2) tanaman cabai +100 ekor kutu kebul dengan 10 pasang predator Menochilus sp., (3) tanaman cabai +100 ekor kutu kebul dengan 10 pasang predator Micraspis sp., (4) tanaman cabai + 100 ekor kebul dengan 10 pasang Paederus sp. Sebagai satuan percobaan adalah 2 tanaman cabai berumur tiga minggu yang diberi kotak kurungan kain kasa berukuran $60 \times 60 \times 100 \mathrm{~cm}$. Pengamatan dilakukan setiap minggu hingga 6 minggu setelah perlakuan. Pengamatan dilakukan terhadap populasi imago kutu kebul yang berada di dalam kurungan. Penghitungan populasi kutu kebul dilakukan dengan menggunakan hand counter. Percobaan tersebut di atas dilakukan dua kali musim pertanaman cabai, yaitu pada musim kemarau dan musim hujan.
Data hasil pengamatan dianalisis dengan sidik ragam dan dilanjutkan dengan uji perbandingan nilai tengah menggunakan BNJ dengan menggunakan program SAS.

Pada bagian lain dirancang suatu percobaan untuk mengetahui hubungan antara populasi kutu kebul dan kejadian penyakit serta hubungannya dengan kehilangan hasil. Pengamatan dilakukan terhadap satuan percobaan yang berisi 25 tanaman cabai. Empat ulangan digunakan pada percobaan tersebut.

\section{HASIL DAN PEMBAHASAN}

Hasil percobaan pada musim kemarau dan musim hujan menunjukkan bahwa tiga jenis predator yang digunakan mampu secara nyata menurunkan populasi kutu kebul pada pertanaman cabai. Setelah 42 hari (6 minggu setelah pelepasan predator), populasi kutu kebul yang berada di dalam kurungan yang berisi predator lebih rendah dibandingkan populasi kutu kebul di dalam kurungan yang tidak ada predatornya (Tabel 1).

Pada pertanaman cabai musim kemarau tidak terlihat perbedaan kemampuan tiga jenis predator. Namun demikian, ketiganya mampu menekan populasi kutu kebul untuk menjadi lebih rendah dibandingkan dengan kontrol. Menochilus dan Micraspis, keduanya anggota Famili Coccinellidae merupakan predator dengan kisaran inang yang cukup luas terutama serangga kelompok kutu-kutuan. Menurut Cock (1993) dalam Gerling (2001), kumbang Menochilus sexmaculatus (Coccinellidae) merupakan predator kutu kebul. Serangga ini mampu memangsa 200 - 400 ekor nimfa

Tabel 1. Pengaruh pelepasan predator terhadap populasi kutu kebul pada pertanaman cabai

\begin{tabular}{lcc}
\hline \multirow{2}{*}{ Perlakuan } & \multicolumn{2}{c}{ Populasi imago kutu kebul (ekor) } \\
\cline { 2 - 3 } & Musim kemarau & Musim hujan \\
\hline Kontrol & $17,22 \mathrm{a}$ & $20,17 \mathrm{a}$ \\
Menochilus sp. & $13,67 \mathrm{~b}$ & $13,94 \mathrm{~b}$ \\
Micraspis sp. & $14,17 \mathrm{~b}$ & $14,44 \mathrm{~b}$ \\
Paederus sp. & $14,72 \mathrm{~b}$ & $9,56 \mathrm{c}$ \\
\hline
\end{tabular}

Keterangan: angka yang diikuti oleh huruf yang sama pada tidak berbeda nyata pada uji $\operatorname{BNJ}(\alpha=0,05)$. 
kutu kebul. Sunil et al. (2007) menyatakan bahwa populasi Menochilus di lapangan tidak terpengaruh oleh kelembaban, temperatur, dan curah hujan. Adapun Micraspis selain memangsa kutu kebul juga mampu memangsa wereng pada pertanaman padi (Galagher, 1995).

Pada musim hujan kumbang Paederus (Coleoptera: Staphylinidae) memiliki kemampuan yang lebih baik dibandingkan dua jenis kumbang lainnya (Tabel 1). Menurut Heinrich (1994), predator ini aktif mencari mangsa pada malam hari dan dapat berenang di air atau pada bagian tanaman. Paederus bersifat polifag, jenis mangsanya adalah kutu kebul, wereng coklat, wereng hijau, wereng zig-zag, dan wereng punggung putih.

Sudiono \& Purnomo (2009) melaporkan hubungan antara populasi kutu kebul dengan keterjadian penyakit kuning menunjukkan korelasi positif, yakni semakin meningkatnya populasi kutu kebul akan meningkatkan keterjadian penyakit kuning pada tanaman cabai. Perkembangan atau penyebaran penyakit tanaman tidak terlepas dari penyebaran patogen di lapangan. Hal ini sesuai dengan kaidah segitiga penyakit yang terdiri dari tanaman inang, patogen dan faktor lingkungan yang mendukung perkembangan penyakit. Kutu kebul dalam hal ini bertindak sebagai vektor penularan penyakit yang demikian penting. Di Indonesia, sejauh ini belum ada laporan yang menyebutkan kutu kebul (Bemisia tabaci) bertindak sebagai hama pada tanaman cabai, meskipun bukan tidak mungkin kutu kebul dapat menjadi hama pada tanaman lain seperti pada tanaman tembakau (Aidawati et al., 2002). Di sejumlah negara menurut Hironao et al. (1995) beberapa spesies kutu kebul kerap menjadi hama penting pada tanaman kapas.

Keberadaan predator ternyata sangat bermanfaat dalam menekan populasi kutu kebul (Tabel 1). Penekanan populasi kutu kebul sangat bermanfaat dalam penekanan kejadian penyakit kuning oleh virus gemini. Hubungan antara populasi kutu kebul dan kejadian penyakit kuning dapat dilihat pada Gambar 1. Pada gambar tersebut terlihat bahwa bertambahnya seekor kutu kubul per 25 tanaman cabai memungkinkan bertambahnya kejadian penyakit kuning sebesar $0,4 \%$. Selanjutnya pada Gambar 2 ditunjukkan bahwa peningkatan kejadian penyakit sebesar $1 \%$ berpotensi menurunkan hasil $0,67 \mathrm{~g}$ per 25 tanaman.

Selain mampu menurunkan populasi kutu kebul, keberadaan predator pada ekosistem pertanian dianggap memiliki kemampuan yang tinggi dalam beradaptasi dengan lingkungan serta memiliki kemampuan memencar yang tinggi dibandingkan jenis musuh alami yang lain (Cisneros \& Rosenheim, 1998). Menurut Wiedmann \& Smith (1997), sifat predator yang umumnya generalis dapat mencegah terjadinya ledakan populasi hama yang menjadi mangsanya.

Gambar 3 menunjukkan bahwa predator yang lebih lama bertahan adalah Micraspis. Hal ini erat kaitannya dengan lama hidup imago Micraspis yang

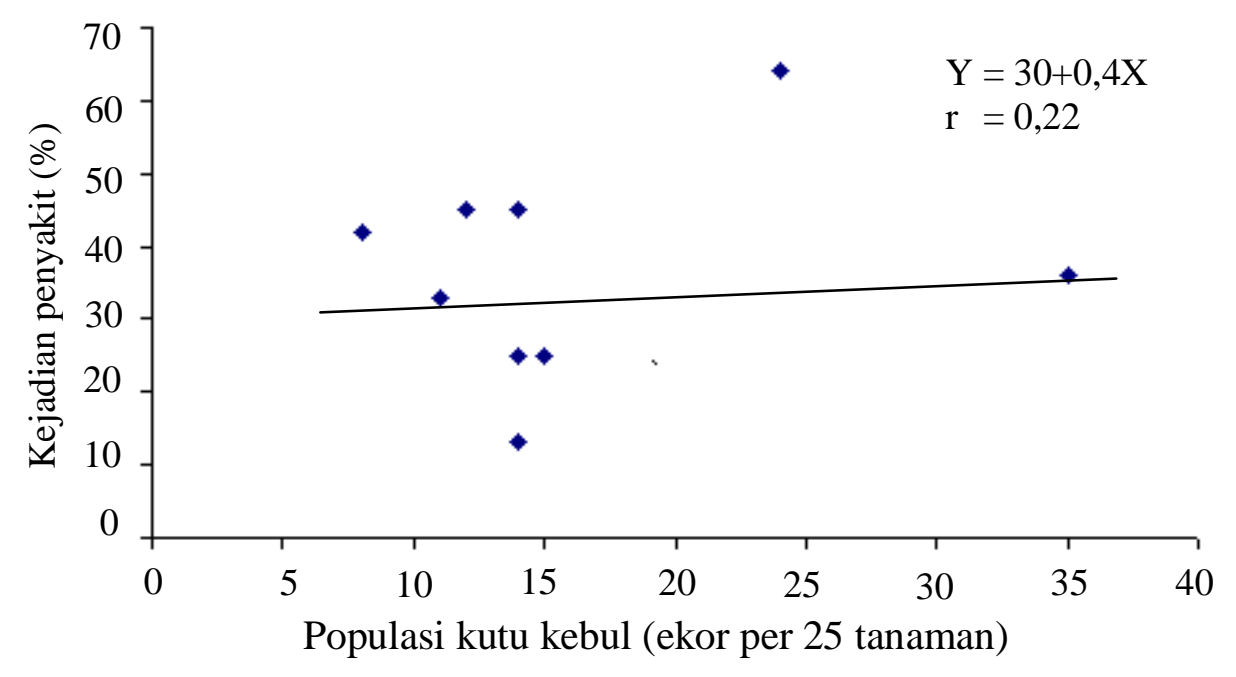

Gambar 1. Hubungan antara populasi kutu kebul dan kejadian penyakit 
memang lebih panjang dibandingkan Menochilus. Hasil penelitian Mari et al. (2004) dan Chowdhury et al. (2008) menyebutkan bahwa lama hidup imago Micraspis lebih dari 40 hari, ada pun lama hidup imago Menochilus \pm 30 hari. Pada Gambar 3 tersebut juga terlihat bahwa populasi predator, seperti halnya populasi kutu kebul ternyata lebih cepat menurun pada musim hujan dibandingkan pada musim kemarau. Salah satu karakter musuh alami yang baik adalah ciri bertautan padat, semakin tinggi populasi inang semakin baik kinerja pemangsaannya, atau sebaliknya ketika populasi inang rendah makan kinerja pemangsaannya akan menurun.

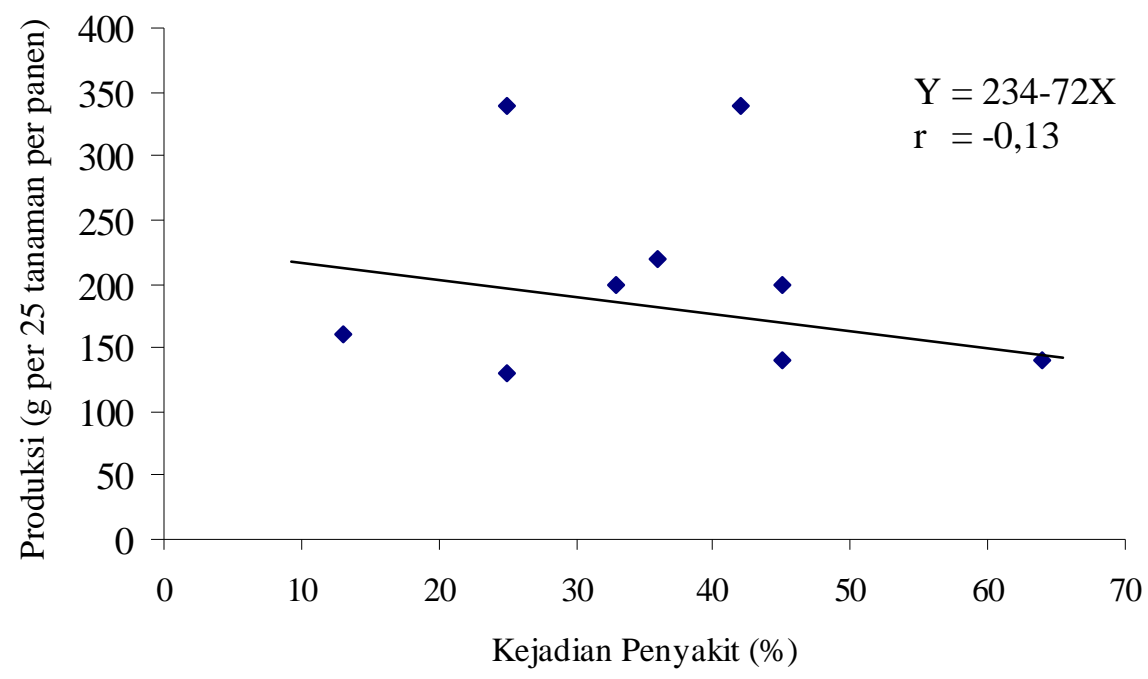

Gambar 2. Hubungan antara kejadian penyakit dan produksi tanaman cabai

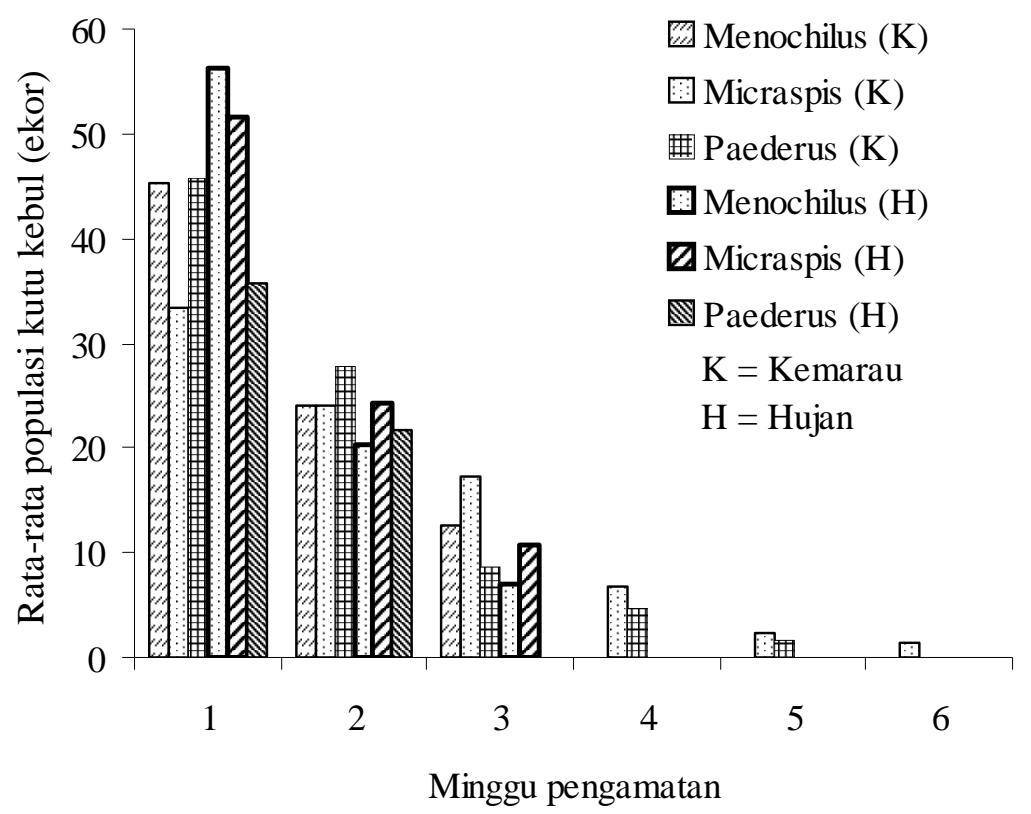

Gambar 3. Pengaruh pelepasan predator terhadap perkembangan populasi kutu kebul selama musim kemarau dan musim hujan 


\section{SIMPULAN}

Penggunaan predator terbukti mampu menurunkan populasi kutu kebul (Bemisia tabaci). Tiga jenis predator: Menochilus, Micraspis, dan Paederus bekerja dengan baik dalam mengendalikan populasi kutu kebul pada pertanaman cabai, terutama pada musim hujan.

\section{DAFTAR PUSTAKA}

Aidawati N, Hidayat SH, Suseno R \& Sosromarsono S. 2002. Transmission of an Indonesian Isolate of Tobacco leaf curl virus (Geminivirus) by Bemisia tabaci Genn. (Hemiptera: Aleyrodidae). Plant Pathol. J. 18(5): 231-236.

Aidawati N, Yusriadi \& Hidayat SH. 2001. Kisaran inang virus gemini asal tanaman cabai dari Guntung Payung, Kalimantan Selatan. Prosiding Kongres dan Seminar Nasional Perhimpunan Fitopaologi Indonesia XVI, Bogor-Jawa Barat.

Bellotti AC \& Arias B. 2001. Host plant resistance to whiteflies with emphasis on cassava as a case study. J. Crop Protection 20(9): 813-823.

Chowdhury SP, Ahad MA, Aimir MR \& Hasan MS. 2008. Biology of Ladybird beetle Micarspis discolors (Fab.) (Coccinelidae: Coleoptera). Int. J. Sustain. Crop Prod. 3(3): 39-44.

Cisneros JJ \& Rosenheim JA. 1998. Changes in the foraging behaviour, within plant vertical distribution, and microhabitat selection of a generalist insect predator: an age analysis. Environ. Entomol. 27(4): 949-957.

Galagher K. 1991. Pengendalian Hama Terpadu untuk Padi, Suatu Pendekatan Ekologi. Proyek Prasarana Fisik Bappenas. Jakarta.

Gerling D, Alomar O \& Arno J. 2001. Biological control of Bemisia tabaci using predator and parasitoids. J. Crop Protection 20(9): 779-799.

Green SK \& Kim JS. 1990. Characterization and control of viruses infecting chilies: a literature review. AVDC Tech. Bull. No. 18.
Heinrich AE. 1994. Biology and Management of Rice Insects. IRRI. Los Banos.

Hilje L, Costa HS \& Stansly PA. 2001. Cultural practices for managing Bemisia tabaci and associated viral diseases. J. Crop Protection 20(9): 801-812.

Hirano K, Budiyanti E, Swatika N \& Fujii K. 1995. Population dynamics of the whitefly, Bemisia tabaci (Gennadius) (Homoptera: Aleyrodidae), in Java, Indonesia, with special reference to spatiotemporal changes in the quantity of food resources. Ecological Research 10: 75-85.

Kalshoven LGE. 1981. The Pests of Crops in Indonesia. Revised and Translated by van der Laan. PT Ichtiar Baru - Van Hoeve. Jakarta.

Mari JM, Nizamani SM, Lobar MK \& Khuhro RD. 2004. Biology of Menochilus sexmaculatus Fab.. and Coccinella undecimpunctata L. on alfalfa aphid Therioaphis trifolii Monell. J. As-Pac. Entomol. 7(3): 297-301.

McAuslanes HJ. 2001. Sweetpotato whitefly B biotype or silverleaf whitefly, Bemisia tabaci (Gennadius) or Bemisia argentifolii Belows and Perring (Insecta: Hemiptera: Aleyrodidae). Institute of Food and Agricultural Sciences (IFAS) University of Florida. EENY-129 (IN286): 19.

Oliveira MRV, Henneberry TJ \& Anderson P. 2001. History, current status, and collaborative research project for Bemisia tabaci. J. Crop Protection 20(9): 709-723.

Palumbo JC, Horowitz AR \& Prabhaker N. 2001. Insecticidal control and resistance management for Bemisia tabaci. J. Crop Protection 20(9): 739-765.

Purnomo, Sulistiya B, Sudiono \& Hariri AM. 2009. Musuh alami kutu kebul (Bemisia tabaci Genn.) pada pertanaman cabai dan sayuran di Tanggamus, Lampung. Prosiding Semirata BKS PTN Wilayah Barat Bidang Ilmu Pertanian Universitas Sultan Ageng Tirtayasa Serang Banten tanggal 13-16 April 2009. 
Rusli ES, Hidayat SH, Suseno R \& Tjahjono B. 1999. Virus gemini asal cabai: kisaran inang dan cara penularan. Bull. HPT. 11(2): 26-31.

Sudiono \& Purnomo. 2009. Hubungan antara populasi kutu kebul (Bemisia tabaci Genn.) dan penyakit kuning pada cabai di Lampung Barat. J. Hama dan Penyakit Tumbuhan Tropika 9(2): 115-120.

Sudiono, Hidayat SH, Suseno R \& Sosromarsono S. 2001. Deteksi molekuler dan uji kisaran inang virus gemini asal tanaman tomat. Prosiding Kongres dan Seminar Nasional Perhimpunan Fitopatologi Indonesia XVI, Bogor-Jawa Barat.

Sudiono, Yasin N, Hidayat SH \& Hidayat P. 2005. Penyebaran dan deteksi molekuler virus gemini penyebab penyakit kuning pada tanaman cabai di Sumatera. J. Hama dan Penyakit Tumbuhan Tropika 5(2): 93-97.
Sulandari S, Suseno R, Hidayat SH, Harjosudarmo J \& Sosromarsono S. 2001. Deteksi virus gemini pada cabai di Daerah Istimewa Jogyakarta. Prosiding Kongres dan Seminar Nasional Perhimpunan Fitopaologi Indonesia XVI, Bogor-Jawa Barat.

Sunil GKr, Laskar N \& Senapati SK. 2007. Seasonal incidence of predator Menochilus sexmaculatus (Berliner) on brinjal and harmful effect of insecticides on the predator. Indian J. Agr. Res. 14(2): abstract.

Trisusilowati EB, Suseno R, Sosromarsono S, Barizi, Soedarmadi \& Nur MA. 1990. Transmissions, serological aspects and morphology of the tobacco krupuk virus. Indonesia. J. Trop. Agric. 1(2): 75-79.

Wildeman RN \& Smith JW. 1997. Attributes of natural enemies in ephemeral crop habitat. Biol. Contr. 10(1): 16-22. 